OPEN ACCESS

Edited by:

Mihri Ozkan,

University of California, USA

Reviewed by:

Lei Li,

Shanghai Jiao Tong University, China Chunlei Wang,

Florida International University, USA

${ }^{*}$ Correspondence:

Güray Güven

gguven@ginerinc.com;

Eileen H. Yu

eileen.yu@newcastle.ac.uk

Specialty section:

This article was submitted to

Nanoenergy Technologies and

Materials,

a section of the journal

Frontiers in Energy Research

Received: 20 August 2015

Accepted: 29 January 2016

Published: 16 February 2016

Citation:

Güven G, Sahin S, Güven A and Yu EH (2016) Power Harvesting from Human Serum in Buckypaper-Based

Enzymatic Biofuel Cell.

Front. Energy Res. 4:4.

doi: 10.3389/fenrg.2016.00004

\section{Power Harvesting from Human Serum in Buckypaper-Based Enzymatic Biofuel Cell}

\author{
Güray Güven ${ }^{1 *}$, Samet Șahin ${ }^{2}$, Arcan Güven ${ }^{3}$ and Eileen H. Yü \\ ' Giner, Inc., Newton, MA, USA, ${ }^{2}$ Chemical Engineering and Advanced Materials, Merz Court, Newcastle University, \\ Newcastle upon Tyne, UK, ${ }^{3}$ Pennsylvania State University College of Medicine, Hershey, PA, USA
}

The requirement for a miniature, high density, long life, and rechargeable power source is common to a vast majority of microsystems, including the implantable devices for medical applications. A model biofuel cell system operating in human serum has been studied for future applications of biomedical and implantable medical devices. Anodic and cathodic electrodes were made of carbon nanotube-buckypaper modified with $\mathrm{PQQ}$-dependent glucose dehydrogenase and laccase, respectively. Modified electrodes were characterized electrochemically and assembled in a biofuel cell setup. Power density of $16.12 \mu \mathrm{W} \mathrm{cm}{ }^{-2}$ was achieved in human serum for lower than physiological glucose concentrations. Increasing the glucose concentration and biofuel cell temperature caused an increase in power output leading up to $49.16 \mu \mathrm{W} \mathrm{cm}{ }^{-2}$.

Keywords: biofuel cell, power production, laccase, PQQ-dependent glucose dehydrogenase, human serum, implantable medical device

\section{INTRODUCTION}

The power requirements are one of the key limiting factors for implantable electronic devices as well as all portable and autonomous electronic systems. Although secondary power cells (e.g., lithium ion) can still be developed to improve on the existing state of the art, biofuel cells introduce a breakthrough concept as recharging can be theoretically achieved with virtually any available biomaterial. Biofuel cells can enable a permanent implantation without the need for surgical replacement, which clearly strengthens the community's competence in this area.

Recently, the possibility of developing implantable enzymatic biofuel cells (EBFCs) has come into focus since these devices would serve as a low-power source to miniature systems within the human body. EBFCs employ glucose as the substrate and oxygen or hydrogen peroxide as oxidizers, in which the power is gained by an oxidation of the biofuel at the anode (Figure 1). The enzymes involved in the process are usually glucose oxidase (GOx), horseradish peroxide (HPR), bilirubin oxidase (BOD), and laccase among the others (Willner et al., 1998; Pizzariello et al., 2002; Mano et al., 2003a,b). The human body is a storehouse of energy. An average person of $68 \mathrm{~kg}$ with $15 \%$ body fat stores energy approximately equivalent to $384540 \mathrm{~kJ}$ (Starner and Paradiso, 2004). However, the body has an abundant supply of energy from the food that we eat. For example, the power consumption of the brain is approximately $0.29 \mathrm{kcal} / \mathrm{min}$ (about $20 \mathrm{~W}$ ) (Angel, 1990). Thus, if even a small fraction of this stored energy could be scavenged, an electronic device would have a large and renewable resource to draw on (Starner and Paradiso, 2004). This may be accomplished through the use of the energy stored within chemicals present in biological fluids, such as glucose (Barrière et al., 2004). 


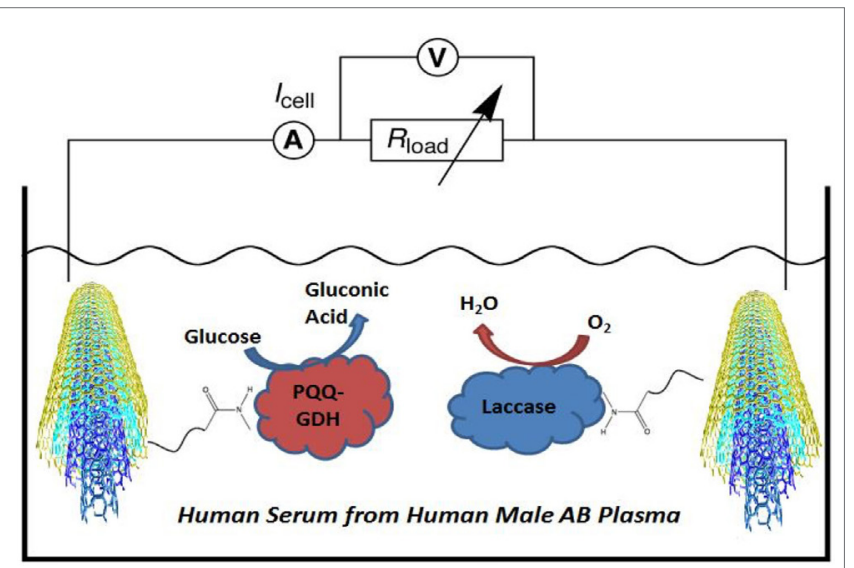

FIGURE 1 | Functionalized MWCNT-buckypaper-based biofuel cell operating in human serum from human male $A B$ plasma

Bioelectrocatalytic reactions are based on the glucose oxidation by the $\mathrm{PQQ}-\mathrm{GDH}$ and $\mathrm{H}_{2} \mathrm{O}_{2}$-reduction by laccase at anode and cathode, respectively.

A variety of electron mediators can be used for the electrical contacting of the biocatalysts and the electrodes. The functionalization of the electrode surfaces with assembled monolayers of redox enzymes, electrocatalysts, and bioelectrozymes (i.e., genetically engineered biocatalysts) (Güven et al., 2010; Yu et al., 2011) can lead to very effective electrical contact (Willner et al., 1998). However, most of these systems would involve the use of diffusional mediators which are dissolved in their respective compartments, and this poses an additional problem for the devices that are intended to be used as power sources for implantable medical devices. Bioelectrocatalytic electrodes, providing efficient non-mediated electric wiring for immobilized enzymes, must be simple in fabrication and stable in electrochemical reaction. A physiological biofuel cell-powered device is in need of constant, reliable, long-term power provided by a body-based biofuel. First in vivo trials with fuel cells, implanted subcutaneously in right flank of adult dog, yielded a power density performance of $2 \mu \mathrm{W} \mathrm{cm} \mathrm{cm}^{-2}$ (Drake et al., 1970) and in a rat (Wan and Tseung, 1974), which was generating $2.9 \mu \mathrm{W} \mathrm{cm}$ of power for a time period of at least $4 \mathrm{~h}$. Although, these earlier results were encouraging with respect to the electricity produced for low-power medical implants, preliminary studies were operated with abiotically catalyzed glucose rather than bioelectrocatalyst reactions. With the aim of developing an EBFC operating in vivo, researchers demonstrated power production from the hemolymph of snails (Halámková et al., 2012), "cyborg” lobsters (MacVittie et al., 2013), and serially connected clams (Szczupak et al., 2012). In addition, a biofuel cell was placed in an insect (Rasmussen et al., 2012). Although first animal experiments were not performed with mammals, studies demonstrated that EBFCs can produce electricity out of living organisms.

Toward human implantable applications, the first demonstration of an implanted biofuel cell (fully biological), generating electricity inside a living organism and, in particular, implanted in a mammal, was in a rat (Cinquin et al., 2010). It was reported that the biofuel cell is able to generate electric power in a rat, using glucose and oxygen contained in its body fluids with an open circuit potential (OCP) of $0.275 \mathrm{~V}$ and maximum power output of $6.5 \mu \mathrm{W}$ (Cinquin et al., 2010). Then, more sturdily constructed biofuel cell prototype was partially (anode compartment only) implanted in rabbit ear (Miyake et al., 2011), which was reflected in the maximum cell current $(1.50 \mu \mathrm{A})$, whereas the power of this cell reached $0.42 \mu \mathrm{W}$ at $0.56 \mathrm{~V}$ and in brain of a living rat with a maximum power of $2 \mu \mathrm{W} \mathrm{cm}$ at a cell voltage of $0.4 \mathrm{~V}$ (Andoralov et al., 2013). Later, with the recent improvements in terms of carbon nanotube $(\mathrm{CNT})$ compression and direct electron transfer, researchers were successful to increase the power $(38.7 \mu \mathrm{W})$ obtained from the implanted biofuel cell in a rat, using a specially designed electronic circuit to charge a capacitor, to run a LED, or a digital thermometer (Zebda et al., 2013). Recently, researchers reported a glucose/oxygen biofuel cell using FAD-dependent glucose dehydrogenase enzyme at the anode side operating in human serum, which produces maximum power densities of $39.5 \pm 1.3$ and $57.5 \pm 5.4 \mu \mathrm{W} \mathrm{cm}{ }^{-2}$ for EFCs at 21 and $37^{\circ} \mathrm{C}$, respectively (Milton et al., 2015).

In our study, the strategy of direct electrochemical communication has been successfully applied with nanostructured buckypaper composed of multi-wall CNTs (Narváez Villarrubia et al., 2011; Strack et al., 2011; Halámková et al., 2012; MacVittie and Katz, 2014). Enzymes were immobilized onto buckypaper by using a heterobifunctional cross-linker, 1-pyrenebutanoic acid succinimidyl ester (PBSE), which provides covalent binding with amino groups of protein lysine residues through the formation of amide bonds and interacts with CNTs via $\pi-\pi$ stacking of the polyaromatic pyrenyl moieties (Strack et al., 2011). PBSE results in a random orientation of the enzyme molecules relative to the electrode surface because of the large number of amino acid groups randomly positioned in the protein structure (Katz, 1994). In the case of a flat, robust electrode surface, direct electrode transfer would not be possible because active centers are buried inside the enzymes and therefore would be far away from the transducer surface (Katz, 1994). However, in the case of a buykypaper, electron access channels of the enzymes can find closer electron transport pathways regardless of the enzyme orientation, allowing efficient communication between the CNTs and the enzyme. Selection of the enzymes to immobilize on the buckypaper is also an important issue. In this study, pyrroloquinoline quinone-dependent glucose dehydrogenase (PQQ-GDH) was selected for the anodic bioelectrode because of the successful bioelectrocatalytic generation of anodic currents in the presence of glucose, when enzyme is tethered to CNT materials (Strack et al., 2013). Eventually, a dehydrogenase-based anode operating in the presence of oxygen did not require complex molecular ensemble to achieve a kinetically preferred electron transfer to the bioelectrode instead of oxygen (Katz et al., 1999). In order to perform potentially favorable biofuel cell operation based on glucose oxidation and oxygen reduction at the anode and cathode electrodes, respectively, oxygen-reducing laccase was selected for the cathodic reaction. Laccase is a well-known biocatalyst that is commonly used in EBFCs (Calabrese Barton et al., 2004), and it is compatible with the buckypaper electrode (Hussein et al., 2011). 
In this study, a model system is demonstrated for the biofuel cells that are operated in human serum. After the preliminary attempts to address the problems of integrated circuitries in a biofuel cell setup, with systems mimicking human physiology (Coman et al., 2010; Southcott et al., 2013), cyclic voltammetry and biofuel cell polarization that were applied for the characterization of the power generated from human serum is presented in this study.

\section{MATERIALS AND METHODS}

\section{Enzyme Preparation}

Pyrroloquinoline quinone-dependent glucose dehydrogenase (E.C. 1.1.5.2) from Microorganism (Toyobo Co., Japan) was used as supplied. Laccase (E.C. 1.10.3.2, from Trametes versicolor) was obtained from Sigma-Aldrich and used in experiments after the purification method as described elsewhere (Strack et al., 2011). Briefly, laccase was dissolved $(5 \mathrm{~mL}, 20 \mathrm{mg} \mathrm{mL}-1)$ in potassium phosphate buffer $(20 \mathrm{mM}, \mathrm{pH} 7.3)$ and dialyzed using a Slide-A-Lyzer dialysis cassette (10 kDa molecular weight cutoff; Thermo Fisher Scientific, Inc.) against a series of sequential buffer exchanges (10 mM potassium phosphate, $\mathrm{pH} 7.0$ for $12 \mathrm{~h}$ at $4^{\circ} \mathrm{C}$ ) containing $1 \mathrm{mM} \mathrm{CuSO}_{4}, 1 \mathrm{mM}$ EDTA, and buffer only. Following dialysis, the protein concentration of the preparation was determined using a bicinchoninic acid protein assay kit (Thermo Fisher Scientific, Inc.). Protein activity in respect to catalytic oxidation was determined for syringaldazine, using the supplier's standard method (Sigma-Aldrich). The laccase preparation was normalized to a defined protein concentration (1.5 $\left.\mathrm{mg} \mathrm{mL}^{-1}\right)$.

\section{Electrode Preparation}

Carbon nanotube-buckypaper prepared from 100\% multi-walled CNTs (Buckeye Composites; NanoTechLabs, Yadkinville, NC, USA) was used as the electrode material $\left(0.25 \mathrm{~cm}^{2}\right.$ geometric area). Electrodes were incubated with $10 \mathrm{mM}$ PBSE (AnaSpec Inc.) in DMSO with moderate shaking for $1 \mathrm{~h}$ at room temperature (RT) and subsequently rinsed in DMSO (5 min) to remove excess PBSE and then in potassium phosphate buffer $(10 \mathrm{mM}, \mathrm{pH} 7.0$; $5 \mathrm{~min})$. The PBSE-functionalized electrodes were immediately incubated with enzyme solutions, for $1 \mathrm{~h}$ at RT with moderate shaking, before washing extensively with potassium phosphate buffer (10 mM, pH 7.0). Enzyme solutions consist of $1 \mathrm{mg} \mathrm{mL}^{-1}$ PQQ-GDH dissolved in potassium phosphate buffer $(10 \mathrm{mM}, \mathrm{pH}$ 7.0) supplemented with $1 \mathrm{mM} \mathrm{CaCl}_{2}$ and $1.5 \mathrm{mg} \mathrm{mL}^{-1}$ of purified laccase for the modification of anode and cathode, respectively. The activity of PQQ-GDH and laccase immobilized on the anode and cathode were reported as 250 and $460 \mathrm{mU}$ per electrode, respectively (Halámková et al., 2012), by performing optical assays as described elsewhere (Holwerda and Gray, 1975; Dewanti and Duine, 1998). The modified electrodes were used immediately or stored $\left(4^{\circ} \mathrm{C}\right)$ in potassium phosphate electrolyte $(0.1 \mathrm{M}, \mathrm{pH} 7.0)$ until used in biofuel cell or electrochemical measurements.

\section{Electrochemical Measurements}

Enzyme (PQQ-GDH or laccase) and cross-linker (PBSE)modified buckypaper electrodes were connected through a copper conductive tape (3M, SPI supplies) to a potentiostat (ECO Chemie Autolab PASTAT 10 electrochemical analyzer, using the GPES 4.9 software package) and used as the working electrode in electrochemical measurements where a Pt wire (Metrohm) and a $\mathrm{Ag}|\mathrm{AgCl}| \mathrm{KCl} 3 \mathrm{M}$ (Metrohm) were used as counter and reference electrodes, respectively. Cyclic voltammograms (CVs) were obtained in the potential range between 0 and $0.8 \mathrm{~V}$ (vs. $\mathrm{Ag} / \mathrm{AgCl}$ ) at a scan rate of $1 \mathrm{mV} \mathrm{s}^{-1}$. CVs of bioanode were tested in sterile-filtered human serum from human male $A B$ plasma (Sigma-Aldrich, Product\# H4522) supplemented with glucose (19.89 mM, final concentration) and a no glucose buffer solution (22 mM NaHCO $3,40 \mathrm{mg} \mathrm{mL}^{-1} \mathrm{BSA}, 6.7 \mathrm{mM} \mathrm{MgCl}_{2}$, $5 \mathrm{mM} \mathrm{KCl}$; $\mathrm{pH}$ 7.4) mimicking in vitro physiological conditions (Roach, 1963), whereas biocathode measurements were achieved in the absence and presence of oxygen (in equilibrium with air). Anaerobic conditions were achieved by purging the solution with nitrogen.

\section{Biofuel Cell Measurements}

The electrodes were modified for the biofuel cell measurements as it is explained above. Biocatalytic electrodes were assembled in human serum solutions. Glucose concentration of the human serum used in this study is $4.89 \mathrm{mM}$ (Ammam and Fransaer, 2010; Ammam and Easton, 2011). The effect of glucose concentration on power output was measured by adding $\mathrm{D}$-glucose (from 4.89 to $24.89 \mathrm{mM}$, final concentration) into human serum solution. The voltage and current generated by the biofuel cell were measured by a digital multimeter (Meterman 37XR). For the determination of the power output, a variable resistance was used as an external load. The measurements were carried out at ambient temperature $\left(23 \pm 2^{\circ} \mathrm{C}\right)$. In order to evaluate the performance of the biofuel cell for in vivo use, it was tested in human serum at $37^{\circ} \mathrm{C}$.

\section{RESULTS AND DISCUSSION}

The biofuel cell anode was characterized using CVs to validate whether the functionalized biocatalytic buckypaper electrodes $\left(0.25 \mathrm{~cm}^{2}\right)$ are capable of electron transfer to the electrodes. Peaks in the voltage-current curves would be observed at potentials corresponding to the potentials of the enzyme active centers, such as PQQ and T1 in GDH (Katz et al., 1999) and laccase (Calabrese Barton et al., 2004), respectively, in order to confirm the direct electrochemistry between the enzyme active center and electrode surface.

Cyclic voltammograms of the PQQ-GDH-modified electrodes were obtained in human serum supplemented with glucose (24.89 mM, final concentration) (Figure 2, blue curve) and in mimicking solution free of glucose (Figure 2, red curve). The anodic currents produced by PQQ-GDH (Figure 2) were observed only in the presence of glucose, which shows the successful immobilization of PQQ-GDH onto PBSE-functionalized CNT-buckypaper electrode. The anodic current produced by the oxidation reaction of the PQQ-GDH electrode was developed at around $0.10-0.15 \mathrm{~V}$ vs. $\mathrm{Ag} / \mathrm{AgCl}$. Previous works have reported that the anodic current produced by the PQQ-GDH electrode appeared at potentials more positive than $-0.1 \mathrm{~V}$ vs. $\mathrm{Ag} / \mathrm{AgCl}$ in a solution mimicking the physiological conditions 


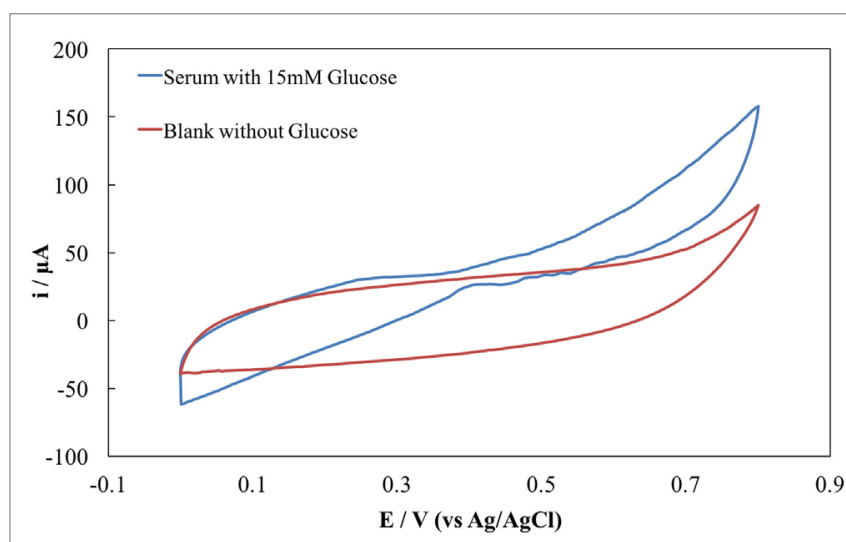

FIGURE 2 | CVs of the PQQ-GDH anode in human serum supplemented with $20.89 \mathrm{mM}$ glucose (blue) and glucose-free mimicking solution (red).

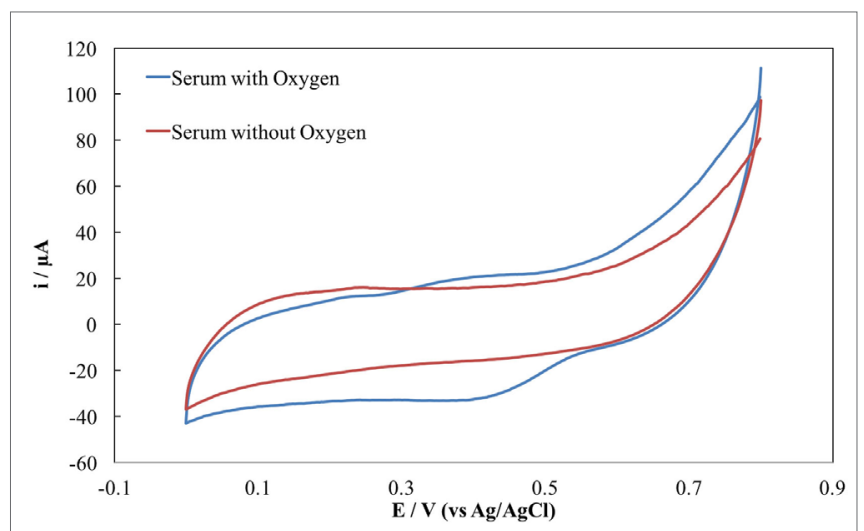

FIGURE 3 | CVs of laccase cathode in human serum in the presence (blue) and absence (red) of oxygen.

(Halámková et al., 2012). The anodic voltage obtained in human serum approximately correspond the values demonstrated in buffer solutions for similar electrodes. Therefore, this result can be interpreted as the electrochemical activity of bioelectrodes. A positive correlation between the glucose concentration and bioelectrocatalytic current (data not shown) reveals the role of the glucose oxidation reaction as a significant source of electrons. The cathodic reaction of laccase-modified electrode is shown in Figure 3. The presence of oxygen in human serum clearly resulted in the formation of bioelectrocatalytic currents (Figure 3, blue curve) where the oxygen reduction peak starts at around $0.50-0.55 \mathrm{~V}$ vs. $\mathrm{Ag} / \mathrm{AgCl}$. The appearance of the cathodic current obtained in human serum is similar to the previously reported currents appearing at ca. $0.58 \mathrm{~V}$ vs. $\mathrm{Ag} / \mathrm{AgCl}$ in other related systems (Strack et al., 2011; Halámková et al., 2012).

The cell electromotive force (EMF) is the potential difference between the anode and the cathode or the voltage of the electrochemical cell. Theoretically, open circuit potential (OCP) should be the difference between anodic and cathodic
TABLE 1 | Summary of the biofuel cell performance results obtained from different human serum samples.

\begin{tabular}{lcc}
\hline & OCP $(\mathbf{V})$ & Maximum power $(\boldsymbol{\mu W})$ \\
\hline Serum & 0.286 & 4.03 \\
Serum $+5 \mathrm{mM}$ glucose & 0.336 & 6.28 \\
Serum $+10 \mathrm{mM}$ glucose & 0.388 & 9.04 \\
Serum $+15 \mathrm{mM}$ glucose & 0.413 & 11.50 \\
Serum $+20 \mathrm{mM}$ glucose & 0.436 & 12.29 \\
Serum at $37^{\circ} \mathrm{C}$ & 0.396 & 8.27
\end{tabular}

potentials, i.e., EMF; however, in practice, the OCP is substantially lower than the theoretical value due to various potential losses, particularly activation/kinetic loss. The anodic and cathodic potential, obtained by the PQQ-GDH and laccase electrodes, were produced at 0.1 and $0.55 \mathrm{~V}$ vs. $\mathrm{Ag} / \mathrm{AgCl}$, respectively. Therefore, the OCP of ca. $0.45 \mathrm{~V}$ between the reactions at the anode and the cathode can be obtained.

After demonstrating the electrochemical activity of biocatalytic oxidation and reduction reactions, electrodes were used for harvesting electrical power from human serum in vitro. The overall performance of the biofuel cell is evaluated by its power output. Power is calculated as

$$
P=i \times E_{\text {cell }}
$$

To evaluate the power generation, a decreasing resistance from $300 \mathrm{k} \Omega$ to $100 \Omega$ at a time interval of $10 \mathrm{~s}$ in each load was applied, and the current and cell potentials for each resistance were measured. Later, the applied resistor, cell potential, and current were used to calculate power. Therefore, it can be said that power generated by biofuel cell was computed as a product of current passing through an external load and voltage drop across the resistor.

The results of the different biofuel cell measurements operating in human serum and different additions of glucose concentrations are summarized in Table 1. The purpose of this experiment was to demonstrate the EBFC operation under different physiological conditions representing different glucose concentrations in human blood. With an attempt to demonstrate the biofuel cell in biomedical applications, human serum solution was spiked with various concentrations of glucose. Thus, final glucose concentrations between 4.89 and $24.89 \mathrm{mM}$ were realized, corresponding to various physiological conditions (i.e., diabetes mellitus and health ranges) (Nelson et al., 2008). The biofuel cell operated in human serum showed an OCP value of $286 \mathrm{mV}$, and it was observed that upon an increase of the load resistance, the recorded power from human serum increased up to a maximum net value of $4.03 \mu \mathrm{W}$ (power density of $16.12 \mu \mathrm{W} \mathrm{cm} \mathrm{cm}^{-2}$ ) at an external load of $10 \mathrm{k} \Omega$. The OCPs of the other human serum samples showed increasing values with increasing glucose concentrations as well as the power output, in which the maximum OCP and power density were $436 \mathrm{mV}$ and $12.29 \mu \mathrm{W}$ (power density of $49.16 \mu \mathrm{W} \mathrm{cm}{ }^{-2}$ ), respectively.

Figures $\mathbf{4}$ and $\mathbf{5}$ show the cell voltage as a function of current density, also known as the polarization curve of the biofuel cell, and the power output of the biofuel cell operating in human serum and different glucose additions, respectively. The power 
generation from biofuel cell reached its maximum values where external resistance was equal to internal resistance (Menicucci et al., 2006), on the load of $10 \mathrm{k} \Omega$ followed by a gradual decay due to mass transport losses as the external load is increased, indicative of typical fuel cell behavior (Bockris and Srinivasan, 1969). At high current density values, the reaction is limited by mass transport of reactants. In most of the cases, it is a sharp decrease of the voltage to 0 at the certain current density value or around it as seen in our data for lower glucose concentrations. With higher glucose concentrations, after peak power is achieved, it was possible to continue polarizing the cell until the voltage dropped to a low value of 0.05 at $20 \mathrm{mM}$ glucose. Further polarizing the cell did not increase current density as voltage dropping, a bend back on polarization curve, can be observed due to mass transport limitation. This is common in biological fuel cells known as "power overshoot."

The shapes of power curves for elevated sugar values in this model system were almost identical where the maximum power output was obtained with different glucose concentrations at the optimum external load of $10 \mathrm{k} \Omega$. Since the variations at power generation represent the current/voltage dependence on the

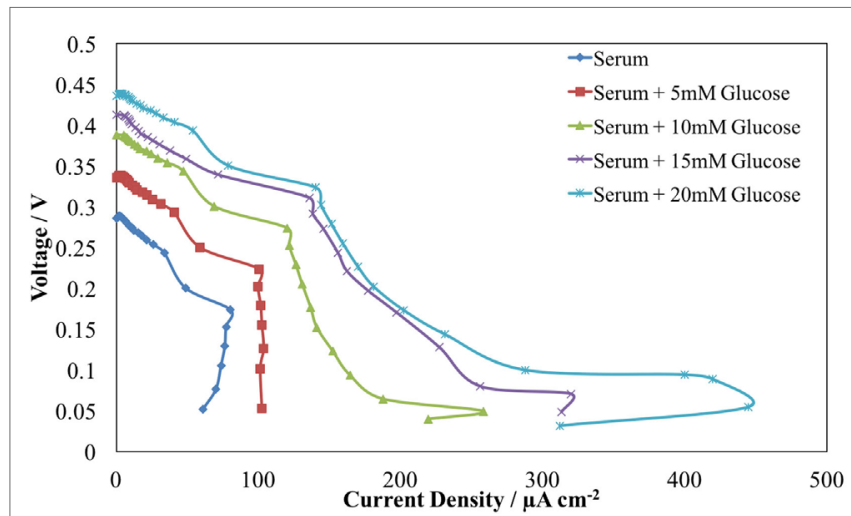

FIGURE 4 | Cell voltage vs. current density curve of the biofuel cell operating in human serum and different glucose additions, at room temperature

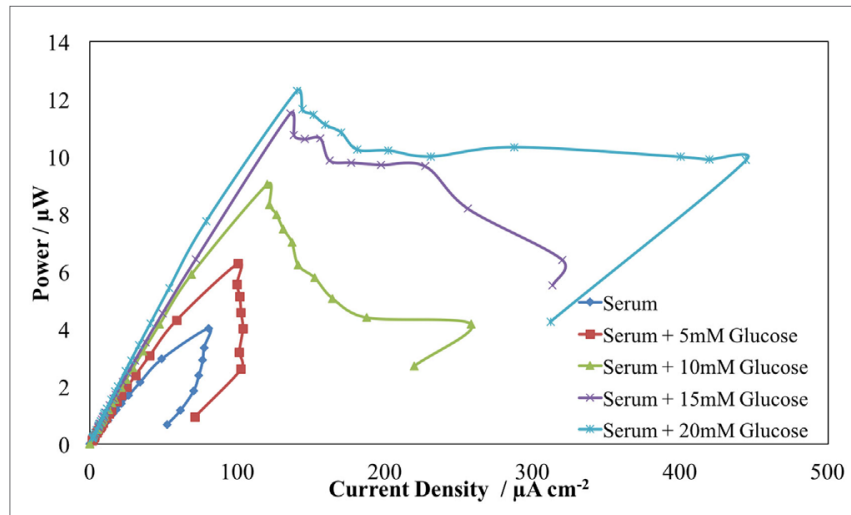

FIGURE 5 | The power output of the fuel cell operating in human serum and different glucose additions, at room temperature. glucose (Castorena-Gonzalez et al., 2013), obtained net power has increased from 4.03 to $12.29 \mu \mathrm{W}$ when the glucose levels were increased from 4.89 to $24.89 \mathrm{mM}$. However, linearity between the power output and glucose concentration was achieved between 4.89 and $19.89 \mathrm{mM}$ (final concentrations) as the saturation level of the glucose concentration was reached for the biofuel cell operation. Figure 6 shows the maximum power generation by the biofuel cell as a function of the glucose concentration at the external load of $10 \mathrm{k} \Omega$. The glucose-sensitive $(0.50 \mu \mathrm{W} / \mathrm{mM})$ biofuel cell is a redox pair of electrodes that generates power proportional to glucose concentration. Such a system can achieve simultaneous power transmission to implantable glucose sensors (Rai and Varadan, 2012) that measure real-time blood glucose as compared to conventional techniques involving drawing blood samples and in vitro processing.

The temperature dependence of the biofuel cell operating in human serum at RT and at $37^{\circ} \mathrm{C}$ was examined without further optimization of the system. The power output showed sensitivity against temperature, and the power production has increased up to $8.27 \mu \mathrm{W}$ at $37^{\circ} \mathrm{C}$, which is almost twofold higher than it is recorded at RT (Figure 7). Moreover, not only similar power curve behavior was observed at $37^{\circ} \mathrm{C}$ but also with applying an

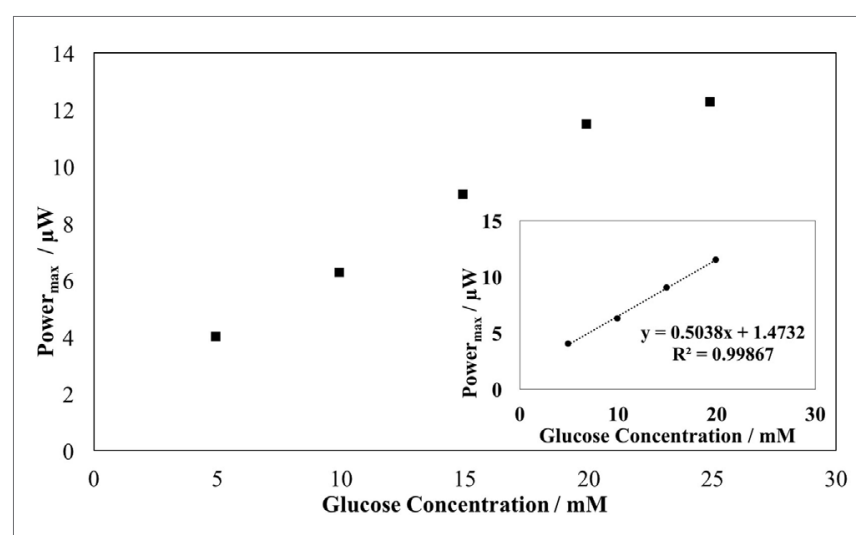

FIGURE 6 | Maximum produced power by the biofuel cell as a function of the glucose concentration at external load of $10 \mathrm{k} \Omega$.

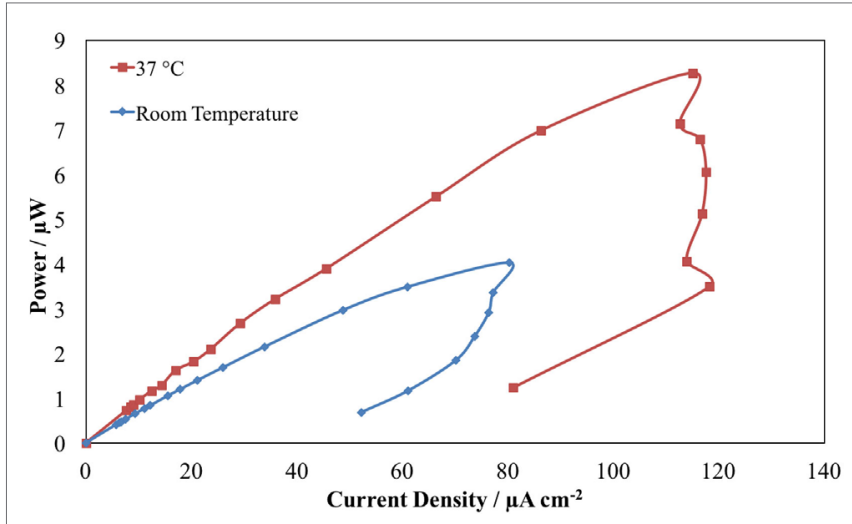

FIGURE 7 | Temperature dependence of the power output of the biofuel cell operating in human serum at RT (blue) and $37^{\circ} \mathrm{C}$ (red). 
external load of $10 \mathrm{k} \Omega$, the biofuel cell produced electrical power demonstrated a relatively long period of stability (at least $3 \mathrm{~h}$ ) at $37^{\circ} \mathrm{C}$, with no medium replacement during the entire experiment. However, the problem about whether the enzymes remain stable for a long period of time is a concern. The efficiency of electron transfer between enzymes and electrodes should be improved.

The enhancement on power output at human body temperature makes biofuel cell operating in human serum an attractive development prospect for use in future applications where power is needed for implantable medical devices.

\section{CONCLUSION}

In this study, a model enzymatic fuel cell was developed CNTbuckypaper with PQQ-GDH on the anode for glucose oxidation and laccase on the cathode for oxygen reduction. The maximum OCP and power density were obtained as $0.44 \mathrm{~V}$ and $12.29 \mu \mathrm{W}$ (power density of $49.16 \mu \mathrm{W} \mathrm{cm} \mathrm{cm}^{-2}$ ), respectively. Additional studies

\section{REFERENCES}

Ammam, M., and Easton, E. B. (2011). High-performance glucose sensor based on glucose oxidase encapsulated in new synthesized platinum nanoparticles supported on carbon Vulcan/Nafion composite deposited on glassy carbon. Sens. Actuators B Chem. 155, 340-346. doi:10.1016/j.snb.2011.04.016

Ammam, M., and Fransaer, J. (2010). Glucose microbiosensor based on glucose oxidase immobilized by AC-EPD: characteristics and performance in human serum and in blood of critically ill rabbits. Sens. Actuators B Chem. 145, 46-53. doi:10.1016/j.snb.2009.11.015

Andoralov, V., Falk, M., Suyatin, D. B., Granmo, M., Sotres, J., Ludwig, R., et al. (2013). Biofuel cell based on microscale nanostructured electrodes with inductive coupling to rat brain neurons. Sci. Rep. 3, 3270. doi:10.1038/srep03270

Angel, A. (1990). Textbook of physiology. 21st edition. two volumes. edited by H. D. Patton, A. F. Fuchs, B. Hille, A. M. Scher and R. Steiner. vol. 1, pp. 769 (1-769); vol. 2, pp. 826 (771-1596). (Harcourt Brace Jovanovich, 1989.). Each volume $£ 64.00$ hardback. vol. 1 ISBN 072162523 1; vol. 2 ISBN 0 $72162524 \mathrm{X}$; both vols 1 and 2 together ISBN 072161990 8. Exp. Physiol. $75,281-281$.

Barrière, F., Ferry, Y., Rochefort, D., and Leech, D. (2004). Targetting redox polymers as mediators for laccase oxygen reduction in a membrane-less biofuel cell. Electrochem. Commun. 6, 237-241. doi:10.1016/j.elecom.2003.12.006

Bockris, J.O’M., Srinivasan, S. (1969). Fuel Cells: Fundamentals and Applications. New York, NY: McGraw-Hill Book Corporation.

Calabrese Barton, S., Gallaway, J., and Atanassov, P. (2004). Enzymatic biofuel cells for implantable and microscale devices. Chem. Rev. 104, 4867-4886. doi:10.1021/cr020719k

Castorena-Gonzalez, J. A., Foote, C., Macvittie, K., Halámek, J., Halámková, L., Martinez-Lemus, L. A., et al. (2013). Biofuel cell operating in vivo in rat. Electroanalysis 25, 1579-1584. doi:10.1002/elan.201300136

Cinquin, P., Gondran, C., Giroud, F., Mazabrard, S., Pellissier, A., Boucher, F., et al. (2010). A glucose biofuel cell implanted in rats. PLoS ONE 5:e10476. doi:10.1371/journal.pone.0010476

Coman, V., Ludwig, R., Harreither, W., Haltrich, D., Gorton, L., Ruzgas, T., et al. (2010). A direct electron transfer-based glucose/oxygen biofuel cell operating in human serum. Fuel Cells 10, 9-16. doi:10.1002/fuce.200900121

Dewanti, A. R., and Duine, J. A. (1998). Reconstitution of membrane-integrated quinoprotein glucose dehydrogenase apoenzyme with PQQ and the holoenzyme's mechanism of action. Biochemistry 37, 6810-6818. doi:10.1021/ bi9722610

Drake, R. F., Kusserow, B. K., Messinger, S., and Matsuda, S. (1970). A tissue implantable fuel cell power supply. ASAIO J. 16, 199-205.

Güven, G., Prodanovic, R., and Schwaneberg, U. (2010). Protein engineering - an option for enzymatic biofuel cell design. Electroanalysis 22, 765-775. doi:10.1002/elan.200980017 for electrochemical characterization of enzyme-immobilized buckypaper electrodes have been achieved. Current studies are underway for further identification of the operational stability of the energy production process but what is undeniable is the proof of principle that human serum can be used as an energy source for biofuel cells.

\section{AUTHOR CONTRIBUTIONS}

All authors listed have made substantial, direct, and intellectual contribution to the work and approved it for publication.

\section{ACKNOWLEDGMENTS}

EY would like to thank EPSRC for the research fellowship (Life Science Interface EP/C535456/1) to support this work. SŞ would like to thank the Turkish Government for the financial support to his Ph.D. study at Newcastle University.

Halámková, L., Halámek, J., Bocharova, V., Szczupak, A., Alfonta, L., and Katz, E. (2012). Implanted biofuel cell operating in a living snail. J. Am. Chem. Soc. 134, 5040-5043. doi:10.1021/ja211714w

Holwerda, R. A., and Gray, H. B. (1975). Kinetics of the reduction of Rhus vernicifera laccase by ferrocyanide ion. J. Am. Chem. Soc. 97, 6036-6041. doi:10.1021/ ja00854a014

Hussein, L., Rubenwolf, S., Von Stetten, F., Urban, G., Zengerle, R., Krueger, M., et al. (2011). A highly efficient buckypaper-based electrode material for mediatorless laccase-catalyzed dioxygen reduction. Biosens. Bioelectron. 26, 4133-4138. doi:10.1016/j.bios.2011.04.008

Katz, E. (1994). An international journal devoted to all aspects of electrode kinetics, interfacial structure, properties of electrolytes, colloid and biological electrochemistry application of bifunctional reagents for immobilization of proteins on a carbon electrode surface: oriented immobilization of photosynthetic reaction centers. J. Electroanal. Chem. 365, 157-164. doi:10.1016/0022-0728(93)02975-N

Katz, E., Willner, I., and Kotlyar, A. B. (1999). A non-compartmentalized glucose| O 2 biofuel cell by bioengineered electrode surfaces. J. Electroanal. Chem. 479, 64-68. doi:10.1016/S0022-0728(99)00425-8

MacVittie, K., Halamek, J., Halamkova, L., Southcott, M., Jemison, W. D., Lobel, R., et al. (2013). From "cyborg" lobsters to a pacemaker powered by implantable biofuel cells. Energy Environ. Sci. 6, 81-86. doi:10.1039/C2EE23209J

MacVittie, K., and Katz, E. (2014). Self-powered electrochemical memristor based on a biofuel cell - towards memristors integrated with biocomputing systems. Chem. Commun. 2014, 4816-4819. doi:10.1039/C4CC01540A

Mano, N., Mao, F., and Heller, A. (2003a). Characteristics of a miniature compartment-less glucose - $\mathrm{O} 2$ biofuel cell and its operation in a living plant. J. Am. Chem. Soc. 125, 6588-6594. doi:10.1021/ja0346328

Mano, N., Mao, F., Shin, W., Chen, T., and Heller, A. (2003b). A miniature biofuel cell operating at 0.78 V. Chem. Commun. 4, 518-519. doi:10.1039/B211796G

Menicucci, J., Beyenal, H., Marsili, E., Veluchamy, R. A., Demir, G., and Lewandowski, Z. (2006). Procedure for determining maximum sustainable power generated by microbial fuel cells. Environ. Sci. Technol. 40, 1062-1068.

Milton, R. D., Lim, K., Hickey, D. P., and Minteer, S. D. (2015). Employing FADdependent glucose dehydrogenase within a glucose/oxygen enzymatic fuel cell operating in human serum. Bioelectrochemistry 106(Pt A), 56-63. doi:10.1016/j. bioelechem.2015.04.005

Miyake, T., Haneda, K., Nagai, N., Yatagawa, Y., Onami, H., Yoshino, S., et al. (2011). Enzymatic biofuel cells designed for direct power generation from biofluids in living organisms. Energy Environ. Sci. 4, 5008-5012. doi:10.1039/ C1EE02200H

Narváez Villarrubia, C. W., Rincón, R. A., Radhakrishnan, V. K., Davis, V., and Atanassov, P. (2011). Methylene green electrodeposited on SWNTs-based "Bucky" papers for NADH and 1-malate oxidation. ACS Appl. Mater. Interfaces 3, 2402-2409. doi:10.1021/am2003137 
Nelson, D. L., Lehninger, A. L., and Cox, M. M. (2008). Lehninger Principles of Biochemistry. Macmillan.

Pizzariello, A., Stred’ansky, M., and Miertuš, S. (2002). A glucose/hydrogen peroxide biofuel cell that uses oxidase and peroxidase as catalysts by composite bulk-modified bioelectrodes based on a solid binding matrix. Bioelectrochemistry 56, 99-105. doi:10.1016/S1567-5394(02)00026-9

Rai, P., and Varadan, V. K. (2012). "Wireless glucose monitoring watch enabled by an implantable self-sustaining glucose sensor system," in Proceedings SPIE 8548, Nanosystems in Engineering and Medicine, 85481G-85481G-85488. doi:10.1117/12.946334

Rasmussen, M., Ritzmann, R. E., Lee, I., Pollack, A. J., and Scherson, D. (2012). An implantable biofuel cell for a live insect. J. Am. Chem. Soc. 134, 1458-1460. doi:10.1021/ja210794c

Roach, D. K. (1963). Analysis of the haemolymph of Arion ater L. (Gastropoda: Pulmonata). J. Exp. Biol. 40, 613-623.

Southcott, M., Macvittie, K., Halamek, J., Halamkova, L., Jemison, W. D., Lobel, R., et al. (2013). A pacemaker powered by an implantable biofuel cell operating under conditions mimicking the human blood circulatory system - battery not included. Phys. Chem. Chem. Phys. 15, 6278-6283. doi:10.1039/C3CP50929J

Starner, T., and Paradiso, J. (2004). "Human generated power for mobile electronics," in Low Power Electronics Design (CRC Press), 1-35.

Strack, G., Babanova, S., Farrington, K. E., Luckarift, H. R., Atanassov, P., and Johnson, G. R. (2013). Enzyme-modified buckypaper for bioelectrocatalysis. J. Electrochem. Soc. 160, G3178-G3182. doi:10.1149/2.028307jes

Strack, G., Luckarift, H. R., Nichols, R., Cozart, K., Katz, E., and Johnson, G. R. (2011). Bioelectrocatalytic generation of directly readable code: harnessing cathodic current for long-term information relay. Chem. Commun. 47, 7662-7664. doi:10.1039/C1CC11475A
Szczupak, A., Halamek, J., Halamkova, L., Bocharova, V., Alfonta, L., and Katz, E. (2012). Living battery - biofuel cells operating in vivo in clams. Energy Environ. Sci. 5, 8891-8895. doi:10.1039/C2EE21626D

Wan, B. Y. C., and Tseung, A. C. C. (1974). Some studies related to electricity generation from biological fuel cells and galvanic cells, in vitro and in vivo. Med. Biol. Eng. 12, 14-28. doi:10.1007/BF02629831

Willner, I., Katz, E., Patolsky, F., and Buckmann, F. A. (1998). Biofuel cell based on glucose oxidase and microperoxidase-11 monolayer-functionalized electrodes. J. Chem. Soc. Perkin Trans. 2, 1817-1822. doi:10.1039/A801487F

Yu, E., Prodanovic, R., Güven, G., Ostafe, R., and Schwaneberg, U. (2011). Electrochemical oxidation of glucose using mutant glucose oxidase from directed protein evolution for biosensor and biofuel cell applications. Appl. Biochem. Biotechnol. 165, 1448-1457. doi:10.1007/s12010-011-9366-0

Zebda, A., Cosnier, S., Alcaraz, J. P., Holzinger, M., Le Goff, A., Gondran, C., et al. (2013). Single glucose biofuel cells implanted in rats power electronic devices. Sci. Rep. 3. doi:10.1038/srep01516

Conflict of Interest Statement: The authors declare that the research was conducted in the absence of any commercial or financial relationships that could be construed as a potential conflict of interest.

Copyright $\odot 2016$ Güven, Sahin, Güven and Yu. This is an open-access article distributed under the terms of the Creative Commons Attribution License (CC BY). The use, distribution or reproduction in other forums is permitted, provided the original author(s) or licensor are credited and that the original publication in this journal is cited, in accordance with accepted academic practice. No use, distribution or reproduction is permitted which does not comply with these terms. 